Vol. 4, No. 1, 2019

\title{
WOOD WASTES UTILIZATION OF THE POKUTTIA-BUKOVYNA CARPATHIANS AS THE RESULT OF INTRODUCTION OF IMPROVED PRODUCTION TECHNOLOGY OF FUEL BRIQUETTES
}

\author{
Andriy Masikevych ${ }^{1}$, Mykhailo Kolotylo ${ }^{2}$, Roman Bat ${ }^{3}$, Yuri Masikevych ${ }^{1}$, \\ Myroslav Malovanyy, ${ }^{4}$ Volodymyr Atamanyuk ${ }^{4}$, Kateryna Petrushka ${ }^{4}$ \\ ${ }^{1}$ Bukovinian State Medical University, \\ 2, Theatralna Sq., 58002, Chernivtsi, Ukraine \\ ${ }^{2}$ National Natural Park "Vizhnitsky”, \\ 27a, Central Str., 59233, Beregomet, Ukraine \\ ${ }^{3}$ Lvivskyy Beton, \\ 1, Gruntova Str., 79066, Lviv, Ukraine \\ ${ }^{4}$ Lviv Polytechnic National University, \\ 12, S. Bandery Str., 79013, Lviv, Ukraine \\ yumasik@meta.ua
}

https://doi.org/10.23939/ep2019.01.024

Received: 4.02 .2019

(C) Masikevych A., Kolotylo M., Bat R., Masikevych Y., Malovanyy M., Atamanyuk V., Petrushka K., 2019

\begin{abstract}
Ecological danger from uncontrolled accumulation of arboreal wastes in the region of PokuttiaBukovyna Carpathians has been estimated. The optimum terms of wood wastes drying in an immobile layer have been studied. The optimum conditions for getting fuel brequettes from wood wastes by the pressing method havw been set. Lignin-containing industrial wastes have been used as a relating component. The principal technological scheme has been offered for fuel granules production from wood wastes by the pressing method.
\end{abstract}

Key words: wood wastes, pressing, fuel brequettes, utilization, the Pokuttia-Bukovyna Carpathians.

\section{Introduction}

The Pokuttia-Bukovyna Carpathians (Fig. 1) is the region of the East Carpathians which has specific landscape, climatic and socio-economic conditions. It is an external strip of Ukrainian (East) Carpathians about $75 \mathrm{~km}$, within the limits of Ivano-Frankivsk and Chernivtsi regions, that stretches from the North-West to the South-East up to the Romania borderline.

Regardless of the similarity of the whole mountain country of the Carpathians, the Pokuttia-Bukovyna Carpathians are characterised by the specific features which determine the level of ecological danger of this region.

Lowland (to $800 \mathrm{~m}$ ) and midland (to $1483 \mathrm{~m}$ ) landscapes prevail in the relief. Slopes are covered mainly with beech forests and with beech-spruce-fir-tree forests.
Higher than $1150 \mathrm{~m}$ above the sea level there are mountain meadows, many mountain pasture-grounds, hayfields, pastures, agricultural lands. There is a high level of ploughed lands (15-18\%), the district is densely populated; the climate is cool and damp (up to $1000 \mathrm{~mm}$ of precipitation a year). The above mentioned peculiarities provided the basis for intensive economic activity, which in combination with natural conditions contributes to the reduction of area covered with forest, destruction of the soil cover, surface washing off, formation of the mudstone phenomena and contamination of water flows, etc. in the basins of the Cheremosh and the Seret rivers.

According to the data of official statistics (www.cv.ukrstat.gov.ua; Bilokon of et al., 2016) the basic forestry districts of the Chernivtsi region which belong to the Pokuttia-Bukovyna Carpathians are Vyzhnytsya and Putyla mountain administrative districts where there are $44.6 \%$ of forests and forest covered areas and $51.2 \%$ of forestry output. At the end of 2014 the forest area of Chernivtsi region provided for the use or ownership was 247 thousand hectares and the residues of only primary waste wood at felling areas were 41.7 thousand of $\mathrm{m}^{3}$ (17720.4 tons), which is $4.45 \%$ to the total. It should be noted that this region has not been studied enough in terms of ecological safety. The development and use of new modern technologies of utilization of wood waste can have a substantial ecological and economic effect for the region of the Pokuttia-Bukovyna Carpathians. 


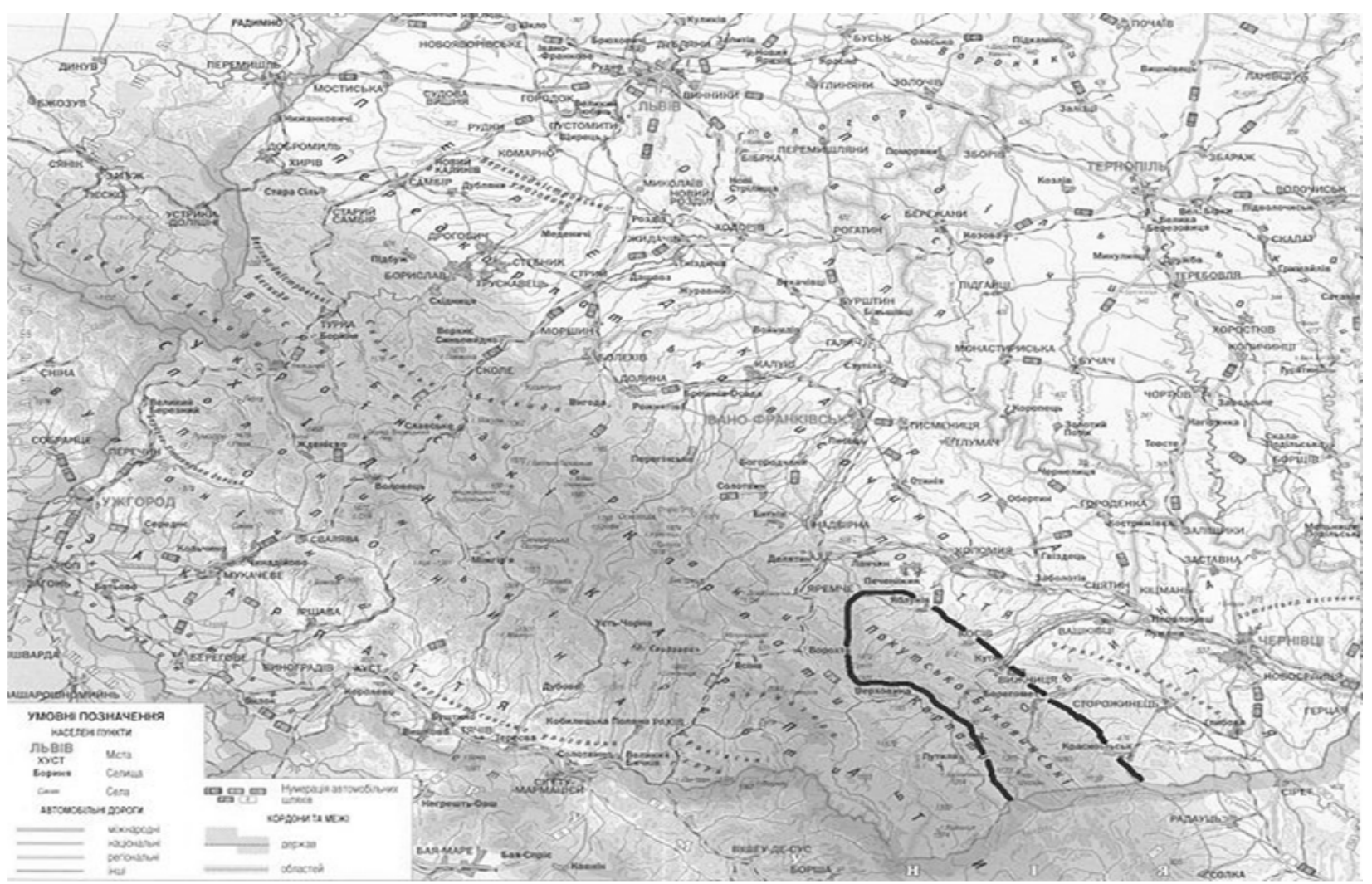

Fig. 1. The Pokuttia-Bukovina Carpathians on the map of Ukraine

The production of energy is associated with global contamination of the atmosphere by carbon dioxide that leads to the greenhouse effect. The concentration of carbon dioxide in the atmosphere of the Earth renewed a record in 2018, reaching 405.5 millionth parts by the volume in 2017. To the present time it was the same only 3-5 million years ago. The Worldwide meteorological organization reported about it in the annual report. The previous record was reached in 2016, the concentration of greenhouse gases in the atmosphere was at the level of 403.3 parts per million [1]. Burning of fossil fuels and some other industrial processes lead to the greenhouse gases emissions into the atmosphere. Scientists consider it to be the reason why global average temperature is rising and the change of climate has been taking place for the last century. The introduction of alternative energy sources will reduce the greenhouse effect. One of the alternative sources of the use is the biomass with significant reserves in Ukraine. During wood processing, which is one of the oldest construction materials, a large amount of waste is generated. In the absence of technology of their utilization these wastes are able to accumulate and this leads to the increase in the amount of greenhouse gases as a result of xylans disintegration (basic wood substances), contamination of water and soils in the districts of dumps of wastes, which causes the silting-up of reservoirs and death of water inhabitants, increase in muddy soils, population of rodents and insects which can become the nurseries of illnesses. One of the most perspective and old known technologies of utilization of wastes from wood processing is burning, which is impossible to be used in other technologies. In this case it is possible to solve the important task of replenishing energy reserves under conditions of minimization of the atmospheric pollution by combustion products [2,3]. It is known that up to 49 million tons of arboreal wastes are formed in Ukraine annually. Their energy is equivalent to $10-20$ billion of $\mathrm{m}^{3}$ of natural gas. At the same time during combustion the equivalent amount of carbon dioxide, which was previously absorbed from the atmosphere during the growth and development of trees, is released into the atmosphere. But for the use of wood as fuel at the industrial scale it is necessary to provide its relative homogeneity by humidity and granulometric composition and favourable conditions for transportation, dosage and storage [4-6].

The typical process of briquettes production used nowadays is their pressing. The process of briquetting is a process of compaction of the material under high pressure, with release of temperature from friction. Due to this lignin which is a binder for the formation of briquettes is released in wood. The higher the pressing force the higher the temperature of the raw material, the better the quality of briquettes. With the increase in the pressing temperature of more than $100{ }^{\circ} \mathrm{C}$ irreversible processes occur which leads to deterioration of product quality. Therefore, for the greatest effect, the temperature in the pressing zone should be within $100{ }^{\circ} \mathrm{C}$. The volume of finished briquettes is $1 / 10$ of the volume of raw materials consumed for their 
production, which gives significant savings during their transportation and storage. Piston and screw presses are used for the production of briquettes [4-6]. But the significant drawback is the considerable energy costs of making briquettes due to the need for creation of high pressure briquetting.

One of the promising ways to solve this problem is to create fuel briquettes using a cheap binder of natural origin. And in the case of using waste from paper production as a binder, the accumulation of which also creates a certain environmental problem, the relevance of the research is even more intense.

The previous investigations [7, 8] have determined that it is promising to use granular or briquetting wood waste by extrusion of a binder of natural origin, namely, sulfate soap (the main part of which is lignin extracted from wood mass in the process of obtaining cellulose). For the formation of fuel briquettes it is necessary to carry out a number of operations, reflected in the form of technology flowchart in Fig. 2.
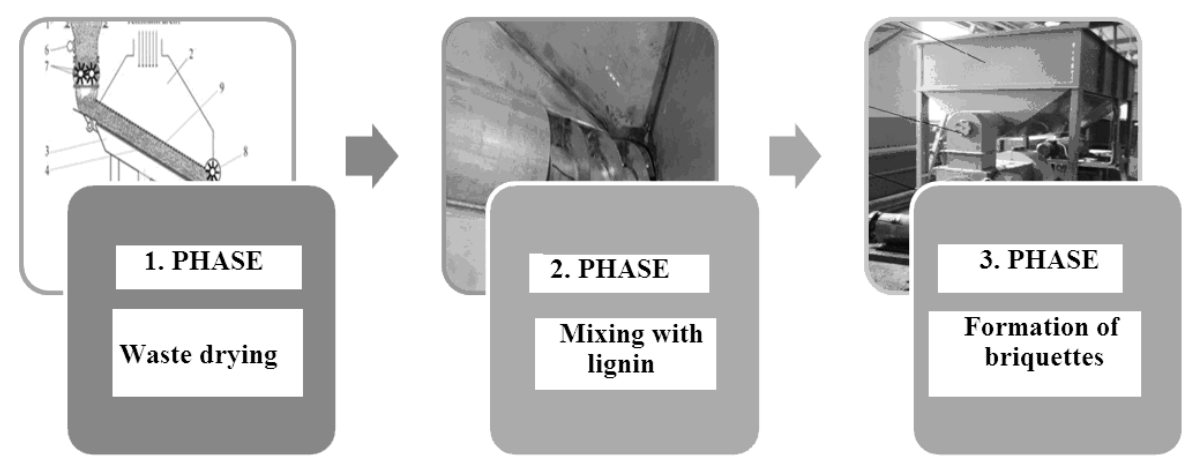

Fig. 2. Tecnology flowchart for the production of fuel granules from wood processing waste

Due to the fact that wood wastes are stored in the open air, its humidity can reach more than $70 \%$ in terms of dry weight. The use of damp raw materials for the production of granules is not feasible due to the low calorific value and the inability to provide the durability of granules. In addition, reducing the amount of moisture that evaporates during combustion improves the operating conditions of the metal elements of the furnace (by reducing the intensity of their corrosion). Therefore, for the further use of wood waste as raw material for the production of granules, they need to be dried to humidity below $10 \%$ in terms of dry weight. We propose to carry out the process of drying wood wastes in a stationary layer.

\section{Experimental part}

For conducting experimental research two experimental samples of wood waste with a specific granulometric composition were used. They are shown in Fig. 3.

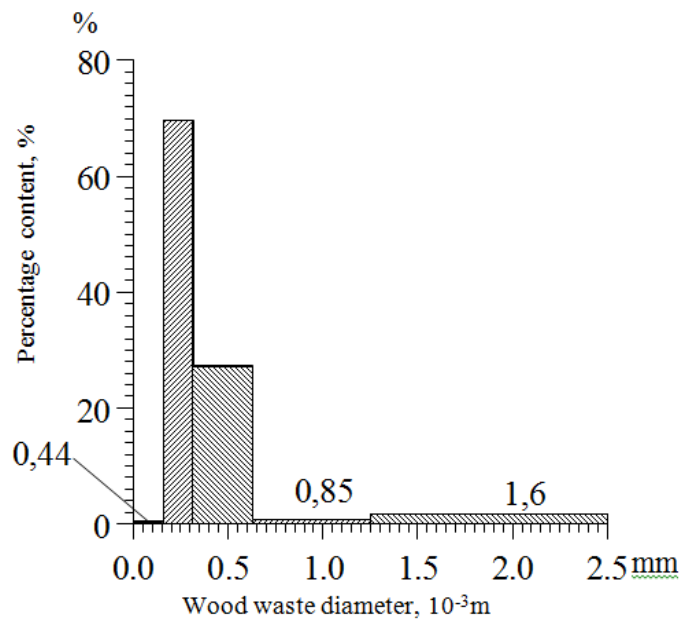

No. 1

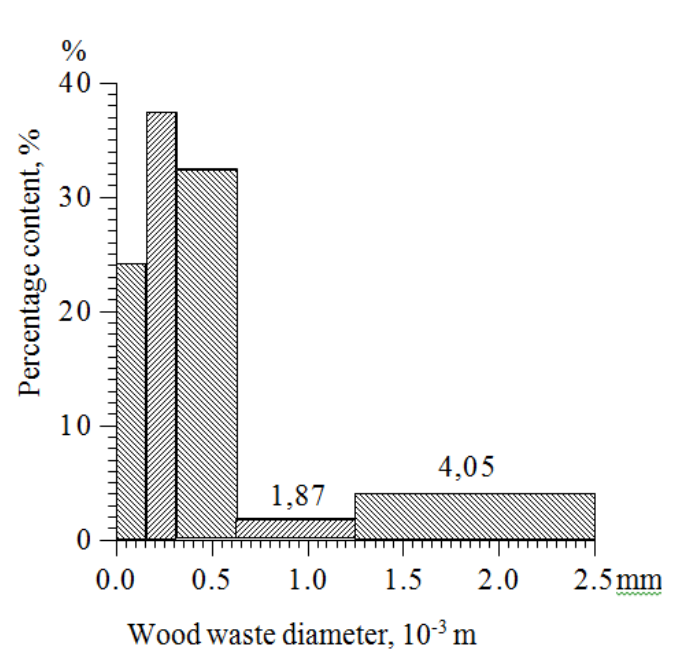

No. 2

Fig. 3. Granulometric composition of wood waste used in the research 
Wastes from Zhydachiv cellulose and paper plant, which are collected from the surface of black meadows after boiling of cellulose from conifers and deciduous trees, were used as a binding component.

In literary sources these wastes occur under the title of sulfate soap. The main component of sulfate soap is lignin derived from wood. The most widespread sulfate soap is made from pine wood. It is the ointment-like dark brown liquid. The composition of sulfate soap also includes a mixture of sodium salts, fatty resin acids and unsaponifiable matter.

Physical and chemical parameters [9]:

- relative density at the temperature of $20{ }^{\circ} \mathrm{C}$ $\mathrm{d}^{20}{ }_{4}=0,6 \ldots 1$;

- moderately soluble in water;

- temperature of self-ignition $400{ }^{\circ} \mathrm{C}$;

- viscosity at $20^{\circ} \mathrm{C} 0.1 \ldots 1.0 \mathrm{~Pa} \cdot \mathrm{s}$, and at $80{ }^{\circ} \mathrm{C}$ $0.09 \ldots 0.45 \mathrm{~Pa} \cdot \mathrm{s}$;

- a complex organic mixture containing 50-55\% $\mathrm{Na}$-salts of higher fatty acids (mainly oleic, linoleic and resin acids);

- the mass fraction of fat, resin acids and nonpolluting substances is not less than $45 \%$;

- mass fraction of water is not more than $35 \%$;

- the mass fraction of totall alkali, calculated as $\mathrm{NaOH}$, is not more than $9 \%$.

The output for $1 \mathrm{t}$ of cellulose: $100-120 \mathrm{~kg}$ of pine, $40-60 \mathrm{~kg}$ of spruce, $20-40 \mathrm{~kg}$ of hardwood [10].

The choice of this binder is due to a number of reasons:

1. these wastes are got when removing tar resin from wood and lignin. This causes non-toxicity and the presence of substances involved in the granulation of high-pressure wood wastes, namely, lignin;

2. significant volumes of formation of these waste.

We have conducted the experimental research on the process of drying forest waste at different heights of the material layer and different temperatures of the thermal agent.

The study of drying wood waste was carried out on the experimental installation, shown in Fig. 4

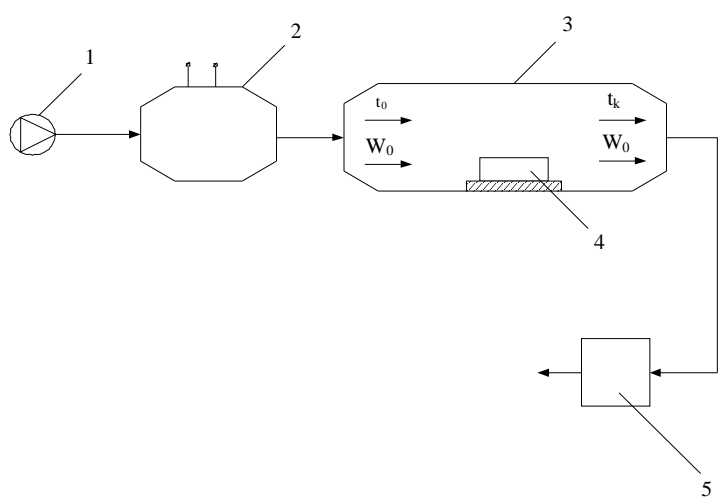

Fig. 4. Scheme of the installation for the research of wood waste drying: 1 - fan; 2 - heater; 3 - drying chamber; 4 - container with a weight; 5 - cleaning system
Investigations on the formation of fuel briquettes were carried out in the mold shown in Fig. 5.

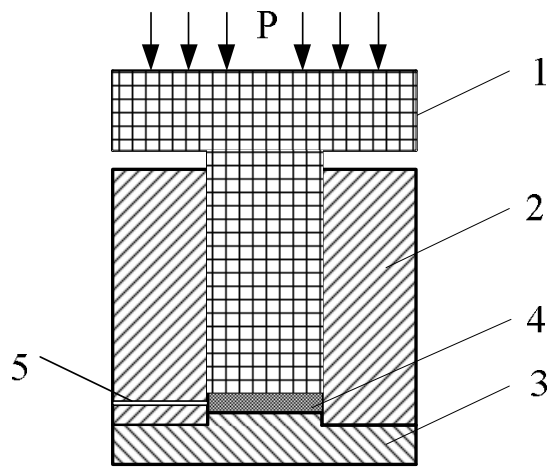

Fig. 5. The picture of the machine for the formation of fuel briquettes: 1 - piston; 2 - matrix; 3 - basis; 4 - composition; 5 - drain hole

The mold consists of a piston 1, a matrix 2, a basis 3 , and a drain hole 5 . The process of the briquette formation was conducted on the hydraulic press inside which the mold for the formation of granules was placed. The source materials with the certain percentage of composition were poured into the machine shown in Fig. 4. The further experiments were conducted with stirring of the components as well as with the adding of the binding component into the center of the wood waste without stirring. The prepared mass was poured into the machine for the briquette formation, after that the machine was put into the hydraulic press where the pressure which formed the briquette was created.

During the experiment the extra binding component with small fraction of wood waste went through the drain hole. After reaching the prescribed pressure, the formed mixture was kept for $10 \mathrm{sec}$. for the ultimate bonding of the particles of the wood waste. Then, a ready briquette was pressed and its physical indications such as mass, height and density were determined.

The process of pressing the briquette formed from wood waste is the following: first, sealing of the material takes place at the expense of reducing the free space between the particles, then goes alteration and sealing of the particles themselves, as a result, molecular adhesion occurs. The further increase of pressure during the process of pressing leads to the formation of not only elastic, but also plastic alterations which increases the power of intermolecular adhesion between finely divided particles and, therefore, the toughness of the briquette. In order to provide the necessary toughness of the briquette the process of pressing is conducted under the pressure of $100-200 \mathrm{MN} / \mathrm{m}^{2}$

To reduce the energy costs of briquette production and provide their high toughness it is expedient to add adherent components to the finely dispersive particles of 
wood waste. In this case, the briquettes of the same quality are formed under the pressure of $10-50 \mathrm{MN} / \mathrm{m}^{2}$

\section{Results and discussion}

The results of the experimental research of the influence of the layer height on the kinetics of drying are shown in Fig. 6. The change in the humidity of wood waste was determined with the weight method.

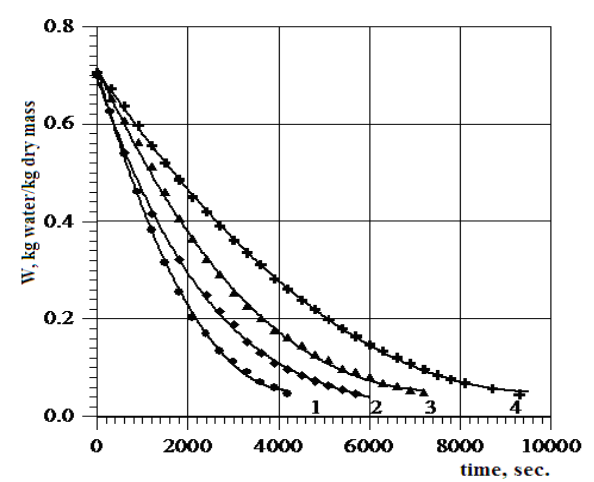

Fig. 6. The kinetics of wood waste drying: $\mathrm{T}=100^{\circ} \mathrm{C}$,

$$
\begin{gathered}
\mathrm{V}_{0}=4,2 \mathrm{~m} / \mathrm{s}: 1-10 \times 10^{-3} \mathrm{~m}, \\
2-20 \times 10^{-3} \mathrm{~m} ; 3-30 \times 10^{-3} \mathrm{~m} ; \\
4-40 \times 10^{-3} \mathrm{~m}
\end{gathered}
$$

In Fig. 6 we can see that with the growth of the layer height of the damp material the duration of drying increases. If the damp material which is $10 \times 10^{-3} \mathrm{~m}$ high reaches the ultimate humidity in $4200 \mathrm{~s}$, the $40 \times 10^{-3} \mathrm{~m}$ high layer reaches it in $9400 \mathrm{~s}$, which can be explained by the diffusion of moisture from the lower layers up to the surface, as well as by the increase in the amount of moisture provided that the height of the damp material increases.

Also, the research on the influence of the heat agent temperature on the kinetics of wood waste drying was conducted. The research showed that with the rise of the temperature the duration of drying decreases. When the temperature of the heat agent is 135 degrees, the damp material reaches its ultimate humidity in $3900 \mathrm{~s}$, and with the temperature of the heat agent 60 degrees - in $7200 \mathrm{~s}$. It is clear that the higher the temperature of the coolant is the shorter the duration of drying will be.

However, the rise of the temperature leads to the increase in heat loss into the environment and to the overheating of upper layers of the material.

Depending on the parameters of drying (the height of the layer, temperature), the process in industrial conditions should be organized differently. Determining the dependence of drying on the technological parameters of the heat agent and the height of the layer is the basis for the development of the drying machine design.

In our case, the conditions will be optimal when the duration of drying and energy costs are minimized. The ultimate duration of drying the sawdust will depend on the height of the layer as well as on the technological parameters of the coolant, exactly, on the temperature and speed of coolant motion. The duration of drying in the first period is determined according to the equation:

$$
\tau_{1}=\frac{1}{N}\left(W_{0}-W_{\kappa p}\right)
$$

In the second period, the duration of drying is determined according to the equation:

$$
\tau_{2}=\tau_{\kappa p}-\frac{\ln \frac{W-W_{p}}{W_{\kappa p}-W_{p}}}{N \aleph}
$$

The general duration of drying up to the ultimate humidity is determined with the equation:

$$
\tau=\tau_{1}+\tau_{2}
$$

In order to choose the optimal parameters of the

\begin{tabular}{|c|c|c|c|c|c|c|c|c|c|}
\hline $\mathrm{H}, \mathrm{m}$ & $\begin{array}{c}\mathrm{T}_{\text {start }}, \\
{ }^{\circ} \mathrm{C}\end{array}$ & $\begin{array}{c}\rho, \\
\mathrm{kg} / \mathrm{m}^{3}\end{array}$ & $\begin{array}{l}\omega_{0,} \\
\mathrm{~m} / \mathrm{s}\end{array}$ & $M=\rho \cdot \omega_{0} \cdot S$ & $\begin{array}{l}\mathrm{T}_{\text {ult }}, \\
{ }^{\circ} \mathrm{C}\end{array}$ & $\tau_{\mathrm{K}}, \mathrm{c}$ & $\begin{array}{l}\text { Q, } \\
\mathrm{kJ}\end{array}$ & $\begin{array}{c}\mathrm{Q}_{\text {dry }} \\
\mathrm{kJ} / \mathrm{kg} \text { dry mass }\end{array}$ & $\begin{array}{c}\mathrm{Q}_{\text {moisture }} \\
\mathrm{kJ} / \mathrm{kg} \text { moisture }\end{array}$ \\
\hline \multicolumn{10}{|c|}{ For different heights of material } \\
\hline 0.010 & 100 & 0.94 & 4.2 & 0.071064 & 90 & 4200 & 3014 & $1.5 \cdot 10^{5}$ & $7.73 \cdot 10^{5}$ \\
\hline 0.020 & 100 & 0.94 & 4.2 & 0.071064 & 90 & 5700 & 4091 & $1.74 \cdot 10^{5}$ & $7.44 \cdot 10^{5}$ \\
\hline 0.030 & 100 & 0.94 & 4.2 & 0.071064 & 90 & 7200 & 5167 & $1.78 \cdot 10^{5}$ & $6.10 \cdot 10^{5}$ \\
\hline 0.040 & 100 & 0.94 & 4.2 & 0.071064 & 90 & 9400 & 6746 & $1.80 \cdot 10^{5}$ & $5.51 \cdot 10^{5}$ \\
\hline \multicolumn{10}{|c|}{ For different temperatures } \\
\hline 0.020 & 135 & 0.94 & 4.2 & 0.071064 & 125 & 3900 & 2799 & $1.10 \cdot 10^{5}$ & $3.85 \cdot 10^{5}$ \\
\hline 0.020 & 100 & 0.94 & 4.2 & 0.071064 & 90 & 5700 & 4091 & $1.74 \cdot 10^{5}$ & $7.44 \cdot 10^{5}$ \\
\hline 0.020 & 80 & 0.94 & 4.2 & 0.071064 & 70 & 6800 & 4880 & $1.89 \cdot 10^{5}$ & $8.04 \cdot 10^{5}$ \\
\hline 0.020 & 60 & 0.94 & 4.2 & 0.071064 & 50 & 7200 & 5167 & $1.94 \cdot 10^{5}$ & $8.76 \cdot 10^{5}$ \\
\hline
\end{tabular}
process we conducted the calculation of the energy cost for the process of drying. The results are shown in Table 1.

Table 1

The choice of the parameters of drying of wood waste $\left(C_{\text {FULL }}=1,01 K J /(K G \cdot K) ; S=0,018 M^{2}\right)$ 
The formation of briquettes was conducted also by the methods of their production under the high extra pressure, the description of which is given in the second part. The briquettes were formed from the wood waste with a certain granulometric composition, the density of the ready briquettes of which was the highest. Different percentage of correlation of binding substance from 4 to $20 \%$ was added to the wood waste. On condition of high concentration which is more than $6 \%$, a significant deletion of binding substance through the drain hole occurred. In some cases, the loss reached $50 \%$, which is unacceptable. So, further, less concentration, from 4 to $6 \%$, was considered. The main criteria for the briquettes were high density, little loss of mass in the process of formation, high static and dynamic strength.

The research on adding different quantities of binding substance $(4 \%, 5 \%$, and $6 \%$ ) with different ways of introducing it into the mass of wood waste was conducted.

Fig. 7 shows the results of the experiments on condition of adding $6 \%$ of binding substance and determining the density of the briquette.

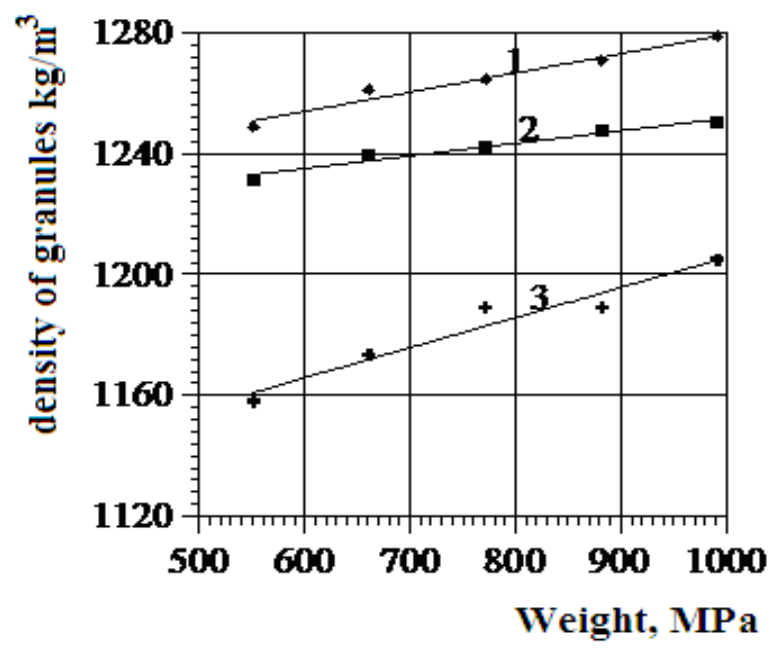

Fig. 7. Change in briquette density on condition of adding $6 \%$ of binding substance depending on the pressure:

1 - feeding the binding substance into the center of mixture; 2 - on condition of stirring the mixture; 3 - wood waste No. 2

The results of the experiments showed that in the case of using binding substance the density of the briquette rises. We can see this dependence in Fig. 7. It is due to better gluing properties provided by the binding component in comparison with the briquettes without binding substance.

On condition of forming a briquette with different percentage of binding substance, the loss of pressed mass through the drain hole occurred which was determined by the difference of mass of the substance before and after it. The results are shown in Fig. 8.

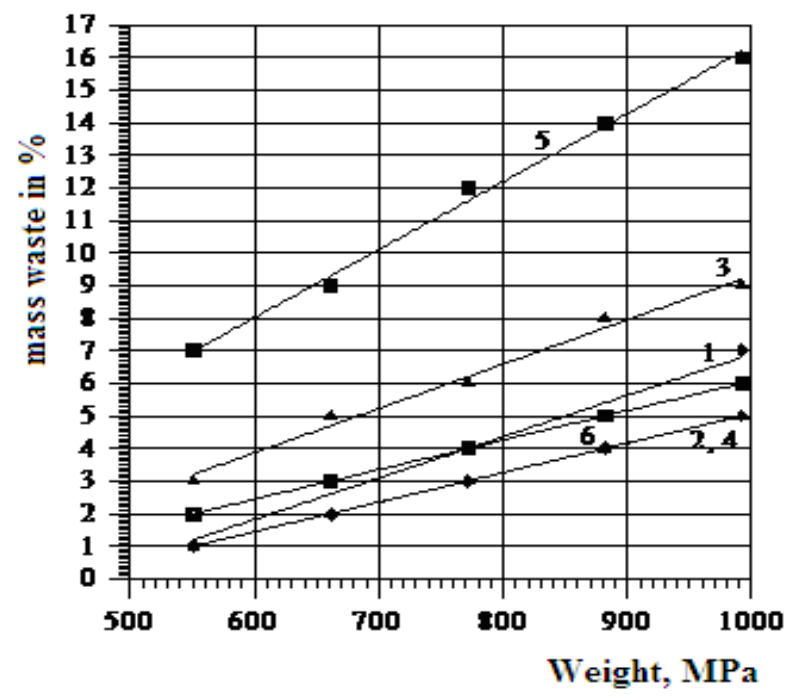

Fig. 8. Change in the mass waste of briquettes, provided that the binder is added depending on the pressure: 1 - the supply of $4 \%$ of the binder into the center of the mixture; 2 - mixing $4 \%$ of the binder with wood waste; 3 - feeding $5 \%$ of the binder into the center of the mixture; 4 - mixing $5 \%$ of the binder with wood waste; 5 - feeding $6 \%$ of the binder into the center of the mixture; 6 - mixing $6 \%$ of the binder with wood waste

According to the results of the experiments (Fig. 8), we can make the following conclusion: the most appropriate method of feeding the binder is mixing; the regular distribution of the binder throughout the mass of wood waste is achieved and in turn it reduces mass loss during the formation of briquettes.

Fig. 9 shows the results of the experiments on determining the static strength of the briquette, under the conditions of adding various concentrations of the binder.

From Fig. 9 it is evident that the static strength increases in those briquettes in which mixing of the binder with the wood waste occurred. This is due to the best distribution of binder in the boundaries of the volume of briquettes with the formation of a reinforcing frame made of wood, and the binder did not allow it to disintegrate.

Fig. 10 shows the technological scheme of the installation for the production of fuel briquettes. Since high pressures are used in the pressing method, it is advisable to produce not small size granules using this method but larger briquettes that are divided into separate pieces.

Pressing of briquettes is carried out using a pressgranulator. The cooling stage is introduced to this 


\section{Andriy Masikevych, Mykhailo Kolotylo, Roman Bat, Yuri Masikevych, Myroslav Malovanyy at all}

technology, which is an important stage in the production of briquettes. After briquetting, the temperature of the briquettes is about $90{ }^{\circ} \mathrm{C}$.

During cooling, the briquette stabilizes, the molten lignin solidifies on the surface of the briquette, so the form of the briquette remains unchanged.

Wood waste is brought by autotransport to the wood waste storehouse 1, for sorting by granulometric composition and storage. Subsequently, the separated wood waste is supplied to the intermediate storehouse 2 .
Wherefrom the waste is supplied to the drying installation 3 , and then to the installation of briquetting (to the press granulator). After leaving the press granulator 4, briquettes are fed for cooling by air in the cooling installation 5 .

Finished briquettes are fed to vibrosieve 6 to remove small particles that are used as fuel in the oven 8 , and suitable ones are sent to the warehouse of the finished products 7. Subsequently, packaging of briquettes and shipment to the consumer takes place.

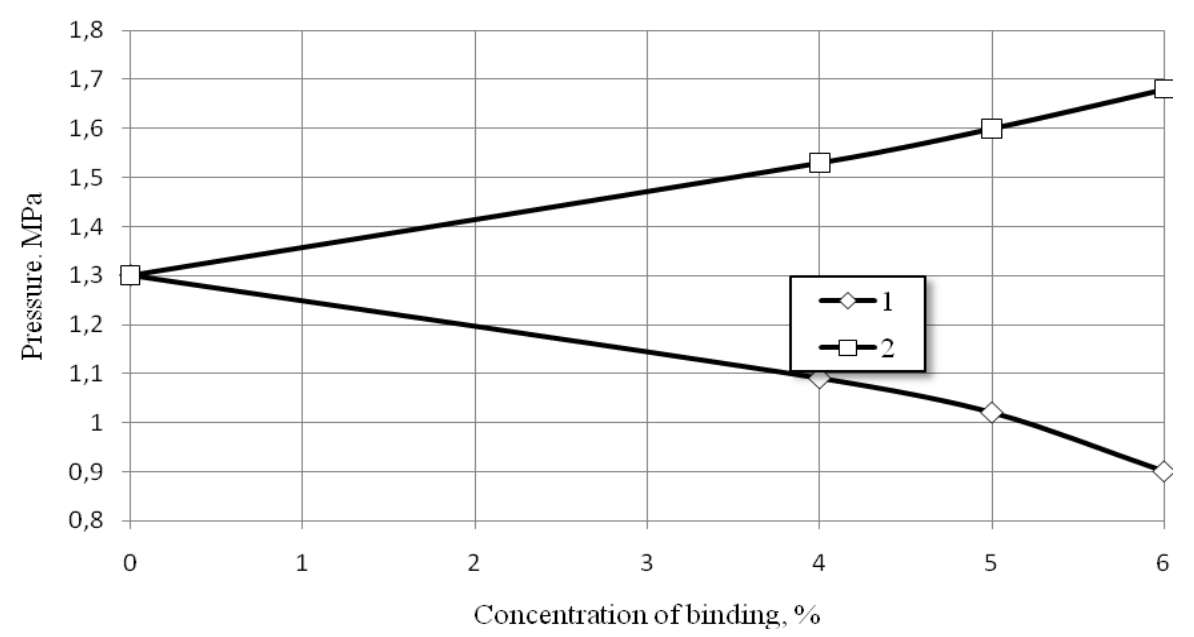

Fig. 9. Change in the static strength of the briquette with different concentrations of the binder, depending on the pressure: 1 - feeding of the binder component into the center of the mixture, 2 - mixing of the binder component with wood waste

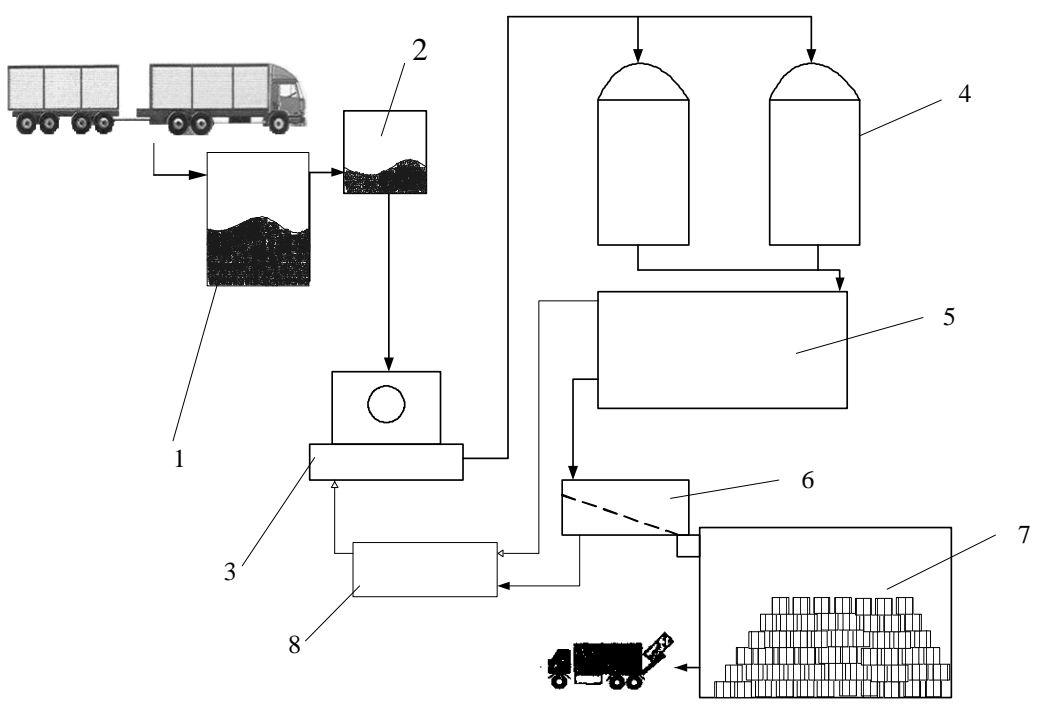

Fig. 10. Principal scheme of briquettes production: 1 - storehouse of wood waste; 2 -intermediate storehouse; 3 -installation for drying; 4 - press granulator; 5 - installation for cooling; 6 - vibrosieve; 7 - warehouse of finished products; 8 - oven

\section{Conclusions}

Ecological danger from the uncontrolled accumulation of wood wastes in the region of the Pokuttia-Bukovyna Carpathians has been estimated. The analysis of the known technology of briquetting of wood waste has been carried out and the strategy of its improvement is substantiated by using the binding component.

The optimum conditions for wood waste drying in the stationary layer have been investigated. The optimum conditions for preliminary drying of raw materials have been established: the height of the layer 
is $20 \times 10^{-3} \mathrm{~m}$, the temperature of the thermal agent is $100{ }^{\circ} \mathrm{C}$.

When using the binder component, briquettes with less pressure are formed, which provides certain statistical strength. The connecting substance acts as a lubricant, which reduces frictional forces, and hence energy costs to overcome them.

An appropriate method of feeding the binder is to mix it with wood waste. The use of the binder has reduced the engine power by $40 \%$, as well as increased the calorific value and the density of the produced fuel briquettes by $20 \%$ and $10 \%$, respectively. The pressure, due to which the formation without the addition of the binder took place, was more than $1 \mathrm{GPa}$, and with the addition of the binder it was from 500 to $990 \mathrm{MPa}$.

The basic technological scheme of production of fuel wood briquettes from wood waste is offered.

\section{References}

[1] Solovii Kh. M. Ochyshchennia stokiv ochysnykh sporud ta utylizatsiia vykydiv vuhlekysloho hazu iz vykorystanniam tsianobakterii: Zbirnyk materialiv. Lviv: Seminar "Stalyi rozvytok - pohliad u maibutnie", 15 veresnia $2017.60 \mathrm{~s}$.
[2] Bekhta P. A. Tekhnolohiia derevynnykh plyt i plastykiv: pidruchnyk. - Kyiv: Osnova, 2004. - 780 s.

[3] Bekhta P. A. Vyrobnytstvo fanery: pidruchnyk. - Kyiv: Osnova, 2003. - 308 s.

[4] yPolishchuk, L. K., Miskov V. P.: Analiz tekhnolohichnykh protsesiv ta obladnannia dlia pererobky derevynnykh materialiv, Visnyk mashynobuduvannia ta transportu, 2017, № 1. - S. 83.

[5] Lotosh V. E. Pererabotka otkhodov pryrodopolzovanyia. Ekaterynburh: Polyhrafyst, 2007. - 503 s.

[6] Homonai M. V. Proyzvodstvo toplyvnukh bryketov. Drevesnoe sure, oborudovanye, tekhnolohyy, rezhymu rabotu: monohrafyia. - M.: HOU VPO MHUL, 2006. - $68 \mathrm{~s}$

[7] Malovanyi M. S., Bat R. Ia. Tekhnolohiia stvorennia biokompozytsii na osnovi vidkhodiv lisovoi ta tseliuloznopaperovoi promyslovosti, Naukovyi visnyk Natsionalnoho lisotekhnichnoho universytetu. - 2006. Vypusk 16.2. - S. 86-88.

[8] Malovanyi M. S., Atamaniuk V. M., Bat R. Ia. Biokompozytsiia na osnovi vidkhodiv derevyny ta naturalnohoviazhuchoho, Rynok instaliatsii. - 2006. 11. - S. 40-41.

[9] Mylo syre sulfatne marky “Z” TU U 00278801.009-98.

[10] Bohdanova E.V. Videlenye y sbor sulfatnoho myla. M.: Knyha, 1974. - $350 \mathrm{~s}$. 